\title{
Discovery of novel TLR modulators by Molecular Modeling and Virtual Screening
}

\author{
Manuela S Murgueitio ${ }^{1 *}$, Sandra Santos-Sierra ${ }^{2}$, Gerhard Wolber ${ }^{1}$ \\ From 7th German Conference on Chemoinformatics: 25 CIC-Workshop \\ Goslar, Germany. 6-8 November 2011
}

Toll-like receptors (TLRs) play a crucial role in the onset of innate immunity by distinguishing between endogenous and pathogen-associated molecular patterns. TLR2, in cooperation with TLR1 and TLR6, recognizes several microbial components such as lipoteichoic acids and lipoproteins [1]. Toll-like receptors have been broadly reported to contribute to several inflammatory chronic diseases and autoimmune diseases [2]. In this study we aim to discover new TLR2 modulating agents through computer-aided drug design.

Based on recently identified synthetic TLR2 agonists [3] and antagonists [4], a shape and chemical-feature based similarity search was performed against a library of 260.071 compounds provided by the National Cancer Institute (NCI) [5]. This led to several virtual hits, which were tested in vitro in a cell-based assay. Several compounds with biological activity on TLR2 signaling in general and TLR1 signaling specifically were identified.

To further optimize these biologically validated virtual hits, molecular interaction fields (MIFs) for the dimerization of TLR2 and TLR1 were developed. Featurebased MIFs allowed for the manual creation of virtual compounds that fulfill an optimized interaction pattern, which led to a 3D pharmacophore that was used for a second virtual screening to select compounds for biological testing.

\section{Author details \\ 'Pharmaceutical Chemistry, Institute of Pharmacy, Freie Universität Berlin, Berlin, Berlin,14195, Germany. ${ }^{2}$ Institute of Biochemical Pharmacology, Medizinische Universität Innsbruck, A-6020, Austria.}

Published: 1 May 2012

\footnotetext{
* Correspondence: m.murgueitio@fu-berlin.de

'Pharmaceutical Chemistry, Institute of Pharmacy, Freie Universität Berlin, Berlin, Berlin,14195, Germany

Full list of author information is available at the end of the article
}

\section{References}

1. Akira S, Takeda K: Toll-like Receptor Signalling. Nat Rev Immunol 2004, 4(7):499-511.

2. Kawai T, Akira S: The role of pattern-recognition receptors in innate immunity: update on Toll-like receptors. Nat Rev Immunol 2010, 11(5):373-384

3. Guan Y, et al: Identification of Novel Synthetic Toll-like Receptor 2 Agonists by High Throughput Screening. J Biol Chem 2010, 258(31):23755-23762.

4. Zhou $S$, et al: Discovery of a novel TLR2 signaling inhibitor with anti-viral activity. Antiviral Res 2010, 87(3):295-306.

5. [http://cactus.nci.nih.gov/download/nci/].

\section{doi:10.1186/1758-2946-4-S1-P58}

Cite this article as: Murgueitio et al:: Discovery of novel TLR modulators by Molecular Modeling and Virtual Screening. Journal of Cheminformatics 2012 4(Suppl 1):P58.

\footnotetext{
Publish with ChemistryCentral and every scientist can read your work free of charge

"Open access provides opportunities to our colleagues in other parts of the globe, by allowing anyone to view the content free of charge."

W. Jeffery Hurst, The Hershey Company.

- available free of charge to the entire scientific community

- peer reviewed and published immediately upon acceptance

- cited in PubMed and archived on PubMed Central

- yours - you keep the copyright

Submit your manuscript here:

http://www.chemistrycentral.com/manuscript/

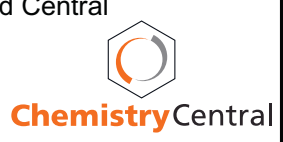

